\title{
Ca-Modified Co/SBA-15 Catalysts for Hydrogen Production through Ethanol Steam Reforming
}

\author{
Josh Y. Z. Chiou1, Siao-Wun Liu ${ }^{1}$, Kuan-Fu Ho ${ }^{1}$, Hsin-Hua Huang ${ }^{1}$, \\ Chih-Wei Tang ${ }^{2}$, Chen-Bin Wang ${ }^{1, *}$ \\ ${ }^{1}$ Department of Chemical and Materials Engineering, Chung Cheng Institute of Technology, \\ National Defense University, Tahsi, Taoyuan, 33509, Taiwan, ROC \\ ${ }^{2}$ Department of General Education, Army Academy ROC, \\ Chungli, Taoyuan, 32092, Taiwan, ROC \\ *E-mail address: chenbinwang@gmail.com , chenbin@ndu.edu.tw
}

\begin{abstract}
Hydrogen production through steam reforming of ethanol (SRE) over the Ca-modified $\mathrm{Co} / \mathrm{SBA}-15$ catalysts was studied herein to evaluate the catalytic activity, stability and the behavior of coke deposition. The Ca-modified SBA-15 supports were prepared from the $\mathrm{Ca}\left(\mathrm{NO}_{3}\right)_{2} \cdot 4 \mathrm{H}_{2} \mathrm{O}(10 \mathrm{wt}$ $\%$ ) which was incorporated to SBA-15 by incipient wetness impregnation (assigned as Ca/SBA-15) and direct hydrothermal (assigned as $\mathrm{Ca}-\mathrm{SBA}-15$ ) method. The active cobalt species from the $\mathrm{Co}\left(\mathrm{NO}_{3}\right)_{2} \cdot 6 \mathrm{H}_{2} \mathrm{O}(10 \mathrm{wt} \%)$ was loaded to $\mathrm{SiO}_{2}$, SBA-15 and modified-SBA-15 supports with incipient wetness impregnation method to obtain the cobalt catalysts (named as $\mathrm{Co} / \mathrm{SiO}_{2}, \mathrm{Co} / \mathrm{SBA}-15, \mathrm{Co}-$ $\mathrm{Ca} / \mathrm{SBA}-15$ and $\mathrm{Co} / \mathrm{Ca}-\mathrm{SBA}-15$, respectively). The prepared catalysts were characterized by using Xray diffraction (XRD), temperature programmed reduction (TPR), transmission electron microscopy (TEM) and BET. The catalytic performance of the SRE reaction was evaluated in a fixed-bed reactor. The results indicated that the $\mathrm{Co} / \mathrm{Ca}-\mathrm{SBA}-15$ catalyst was preferential among these catalysts and the ethanol can be converted completely at $375{ }^{\circ} \mathrm{C}$. The hydrogen yield $\left(\mathrm{Y}_{\mathrm{H} 2}\right)$ approached 4.76 at $500{ }^{\circ} \mathrm{C}$ and less coke deposited. Further, the long-term stability test of this catalyst approached $100 \mathrm{~h}$ at 500 ${ }^{\circ} \mathrm{C}$ and did not deactivate.
\end{abstract}

Keywords: Cobalt catalysts; Ethanol; Steam reforming

\section{INTRODUCTION}

Nowadays, hydrogen becomes the clean and most promising carbon free energy carrier for fuel cells, i.e. proton exchange membrane fuel cells (PEMFCs) that can provide highly efficient electric power for both mobile and stationary applications [1]. It can be stored and delivered in a usable form, but it must be produced on-board from hydrocarbons or liquid fuels, i.e. alcohol like ethanol, which has received much attention due to several advantages when compared to hydrocarbons. From the environmental point of view the use of ethanol is preferred because renewable ethanol obtained from biomass offers high hydrogen content, non-toxicity, safe storage and easy handling [2-4]. Ethanol can be catalytically converted with active metals or metal oxides through steam reforming into a $\mathrm{H}_{2}$-rich gas at a moderate temperature (range $300{ }^{\circ} \mathrm{C}$ to $600{ }^{\circ} \mathrm{C}$ ) [5-10]. Among these, Co-based catalysts exhibit appreciable activities for the $\mathrm{C}-\mathrm{C}$ bond broken and water-gas shift (WGS) reaction. 
Supported cobalt catalysts showed a significant improvement of the catalytic performance, such as the low reaction temperature and low by-products are efficient in the SRE reaction. Haga et al. [11] found that the properties of the cobalt catalysts were greatly influenced by the supports. Among these catalysts, the $\mathrm{Co} / \mathrm{Al}_{2} \mathrm{O}_{3}$ catalyst showed high hydrogen selectivity for SRE by suppressing the CO methanation and the ethanol decomposition. Llorca et al. [5] focused on the various oxides as supports that included acidic/basic and redox properties. In the designing of high efficiency SRE over $\mathrm{Co} / \mathrm{Al}_{2} \mathrm{O}_{3}$ and $\mathrm{Co} / \mathrm{SiO}{ }_{2}$ catalysts, Batista et al. [1] showed that the $\mathrm{Co} / \mathrm{SiO}_{2}$ catalyst possessed better $\mathrm{CO}$ removal capacity. Llorca et al. [12] reported that the prepared $\mathrm{Co} / \mathrm{ZnO}$ catalyst from $\mathrm{Co}_{2}(\mathrm{CO})_{8}$ precursor could obtain $\mathrm{CO}$-free hydrogen and highly stable on the SRE reaction.

In order to improve the catalytic performance of a catalyst, doping extra components to modify the catalyst is one method, the metals such as alkali ( $\mathrm{Li}, \mathrm{Na}$ and $\mathrm{K}$ ) [13], alkaline earth ( $\mathrm{Mg}$ and $\mathrm{Ca})$ [14, 15] and lanthanide ( $\mathrm{La}$ and $\mathrm{Ce}$ ) [15] have been doped. Pigos et al. [13] reported that the addition of $\mathrm{Na}$ and $\mathrm{K}$ over $\mathrm{Pt} / \mathrm{ZrO}_{2}$ catalyst significantly improved the formate decomposition rates on the WGS reaction. Wang et al. [14] reported that the addition of $\mathrm{Na}$ improved the catalytic performance of the $\mathrm{PtRu} / \mathrm{ZrO}_{2}$ catalyst for oxidative steam reforming of ethanol, where the added Na not only enhanced the WGS at low temperature, but also depressed the coke. Cheng et al. [15] suggested that the doped alkaline earth or lanthanide oxides in $\mathrm{Ni} / \mathrm{Al}_{2} \mathrm{O}_{3}$ catalyst can promote the reforming $\mathrm{CH}_{4}$ with $\mathrm{CO}_{2}$.

Besides the above method, the choice of support with high surface area to disperse metal phase is the other way. The support materials such as ZSM-5 [16], MCM-41 [17] and SBA-15 [18] have been widely used in recently years, based on their large pores, thick walls and high thermal stability for high temperature catalytic reaction. Based on this regard, mesoporous material as support is considerable interest that gives an improvement on hydrogen production via steam reforming reaction [19-24]. Effect of alkaline earth metals ( $\mathrm{Mg}$ and $\mathrm{Ca}$ ) as promoter over $\mathrm{Cu}-\mathrm{Ni} / \mathrm{SBA}-15$ [21] and $\mathrm{Cu}-\mathrm{Ni} / \mathrm{SiO}_{2}$ [23] catalysts have been studied; both of them improved the dispersion of the metallic phase and metal-support interaction, where high hydrogen selectivity was obtained with $\mathrm{Mg}$, while the incorporation of $\mathrm{Ca}$ depressed the coke deposition. Wang et al. [24] reported that pre-coating $\mathrm{Ce}_{\mathrm{x}} \mathrm{Zr}_{1-\mathrm{x}} \mathrm{O}_{2}$ layer on Ni-based SBA-15 catalyst can improve the redox property and enhance the catalytic activity on steam reforming of methane. Co-based catalysts are well known to consider on the SRE reaction, while deactivation by the deposited carbon can not be avoided [25]. The SBA15 supported Co-based catalysts with high surface area and modified by the Ca have been prepared in this work. This study aimed to develop a highly efficient and more stable Cobased catalyst for the SRE reaction to generate high $\mathrm{H}_{2}$ and low $\mathrm{CO}$ selectivity in the outlet gas, which could facilitate relatively easier down-steam CO clean-up of PEMFC application. The behavior of coke via the SRE reaction is also considered.

\section{EXPERIMENTAL}

\section{1. Catalyst Preparation}

SBA-15 was prepared according to the method descrobed in the literature [18]. A triblock coplymer P123 (8 g, Strem) was dissolved in a solution of the $250 \mathrm{~mL} \mathrm{HCl}(1.9$ M).The solution was stirred at $40{ }^{\circ} \mathrm{C}$ for $2 \mathrm{~h}$, and $16 \mathrm{~g}$ of tetraethyl orthosilicate (TEOS) was then solwly added to the mixture with vigorous stirring at $40{ }^{\circ} \mathrm{C}$ for $22 \mathrm{~h}$. The solution was transferred into a Telfon bottle and aged at $100{ }^{\circ} \mathrm{C}$ for $24 \mathrm{~h}$. The solid product was filtered, washed with deionized water and then dried at room temperature for $24 \mathrm{~h}$, followed by 
calcination in air at $500{ }^{\circ} \mathrm{C}$ for $6 \mathrm{~h}$. The $\mathrm{SiO}_{2}$ support was a commercial from Aldrich (506 $\left.\mathrm{m}^{2} / \mathrm{g}\right)$.

The Ca-modified SBA-15 supports were prepared from the $\mathrm{Ca}\left(\mathrm{NO}_{3}\right)_{2} \cdot 4 \mathrm{H}_{2} \mathrm{O}(10 \mathrm{wt} \%)$ which was incorporated to SBA-15 by incipient wetness impregnation (assigned as $\mathrm{Ca} / \mathrm{SBA}-$ 15) and direct hydrothermal (assigned as Ca-SBA-15) method. Obtained solid product was filtered, washed with deionized water and then dried at room temperature for $24 \mathrm{~h}$, followed by calcination in air at $550{ }^{\circ} \mathrm{C}$ for $5 \mathrm{~h}$. The active cobalt species from the $\mathrm{Co}\left(\mathrm{NO}_{3}\right)_{2} \cdot 6 \mathrm{H}_{2} \mathrm{O}(10$ wt \%) was loaded to $\mathrm{SiO}_{2}$, SBA-15 and modified-SBA-15 supports with incipient wetness impregnation method. All samples were dried at $100{ }^{\circ} \mathrm{C}$ overnight and then calcined at 300 ${ }^{\circ} \mathrm{C}$ for $3 \mathrm{~h}$ to obtain the cobalt catalysts (named as $\mathrm{Co} / \mathrm{SiO}_{2}, \mathrm{Co} / \mathrm{SBA}-15, \mathrm{Co}-\mathrm{Ca} / \mathrm{SBA}-15$ and $\mathrm{Co} / \mathrm{Ca}-\mathrm{SBA}-15$, respectively).

\section{2. Catalyst Characterization}

The metal loadings of catalysts were determined by the atomic-emission technique (ICP-AES) using a Perkin Elmer Optima 3000 DV instrument. The BET surface area and pore size distribution of the catalysts were measured by $\mathrm{N}_{2}$ adsorption at liquid $\mathrm{N}_{2}$ temperature using Micromeritics ASAP 2010 analyzer. X-ray diffraction (XRD) measurement was performed using a Siemens D5000 diffractometer with $\mathrm{Cu} \mathrm{K}_{\alpha 1}$ radiation $(\lambda=1.5406 \AA)$ at $40 \mathrm{kV}$ and $30 \mathrm{~mA}$. The microstructure and particle size of the samples were observed by using transmission electron microscopy (TEM) with a JEOL JEM-2010 microscope equipped with a field emission electron source and operated at $200 \mathrm{kV}$. The elemental analysis (EA) of the carbon was determined by a HERAEUS VarioEL-III analyzer. Reduction behavior of the catalysts was studied by temperature programmed reduction (TPR). About $50 \mathrm{mg}$ sample was heated in a flowing $10 \% \mathrm{H}_{2} / \mathrm{N}_{2}$ gas $\left(10 \mathrm{ml} \cdot \mathrm{min}^{-1}\right)$ with a heating rate $7{ }^{\circ} \mathrm{C} \cdot \mathrm{min}^{-1}$ from room temperature to $800{ }^{\circ} \mathrm{C}$. Hydrogen consumption was detected by a thermal conductivity detector (TCD).

\section{3. Activity test}

Catalytic activity of SBA-15-supported cobalt catalysts toward SRE reaction were performed at atmospheric pressure in a fixed-bed flow reactor. A catalyst amount of $100 \mathrm{mg}$ was placed in a $4 \mathrm{~mm}$ i.d. quartz tubular reactor, held by glass-wool plugs. The temperature of the reactor was controlled by a heating tape, and measured by a thermocouple $(1.2 \mathrm{~mm}$ i.d.) at the center of the reactor bed. The feed of the reactants was comprised of a gaseous mixture of ethanol $(\mathrm{EtOH}), \mathrm{H}_{2} \mathrm{O}$ and $\mathrm{Ar}$ (purity $99.9995 \%$, supplied by a mass flow controller). The composition of the reactant mixture $\left(\mathrm{H}_{2} \mathrm{O} / \mathrm{EtOH} / \mathrm{Ar}=37 / 3 / 60\right.$ vol. \%) was controlled by a flow Ar stream $\left(22 \mathrm{ml} \cdot \mathrm{min}^{-1}\right)$ through a saturator (maintained $120{ }^{\circ} \mathrm{C}$ ) containing EtOH and $\mathrm{H}_{2} \mathrm{O}$. The gas hourly space velocity (GHSV) was maintained at 23,000 $\mathrm{h}^{-1}$ and $\mathrm{H}_{2} \mathrm{O} / \mathrm{EtOH}$ molar ratio was $13\left(\mathrm{H}_{2} \mathrm{O}: \mathrm{EtOH}=80: 20\right.$ by volume $)$. Prior to the reaction, the sample was activated under air at $400{ }^{\circ} \mathrm{C}$ for $3 \mathrm{~h}$. The SRE activity was tested stepwise, while increasing the temperature from 250 to $500{ }^{\circ} \mathrm{C}$. The reaction products were separated with columns of Porapak Q (for $\mathrm{CO}_{2}, \mathrm{H}_{2} \mathrm{O}, \mathrm{C}_{2} \mathrm{H}_{4}, \mathrm{CH}_{3} \mathrm{CHO}, \mathrm{CH}_{3} \mathrm{OCH}_{3}$ and $\mathrm{EtOH}$ ) and Molecular Sieve $5 \AA$ (for $\mathrm{H}_{2}, \mathrm{CH}_{4}$ and $\mathrm{CO}$ ) and quantitatively analyzed by two sets of TCD-GC on line. Response factors for all products were obtained and the system was calibrated with appropriate standards before each catalytic test. Ethanol conversion $\left(\mathrm{X}_{\mathrm{EtOH}}\right)$, hydrogen yield $\left(\mathrm{Y}_{\mathrm{H} 2}\right)$ and products selectivity $\left(\mathrm{S}_{\mathrm{i}}\right)$ was evaluated and calculated according to the following equations, where $\sum n_{\mathrm{i}}$ was included the $\mathrm{H}_{2}$. 


$$
\begin{aligned}
& \mathrm{X}_{\mathrm{EtOH}}=n_{\mathrm{EtOH}, \text { reacted }} / n_{\mathrm{EtOH}, \text { fed }} \times 100 \% \\
& \mathrm{Y}_{\mathrm{H} 2}=n_{\mathrm{H} 2 \text {-out }} / n_{\mathrm{EtOH}, \text { reacted }} \\
& \mathrm{S}_{\mathrm{i}}=n_{\mathrm{i}} / \sum n_{\mathrm{i}} \times 100 \%
\end{aligned}
$$

\section{RESULTS AND DISCUSSION}

\section{1. Characterization of fresh catalyst}

XRD patterns of the silica-supported cobalt catalysts are shown in Fig. 1. Small-angle XRD patterns [Fig. 1(A)] show that the main diffraction peaks assigned to (100), (110) and (200) reflections, respectively, which indicate that the ordered hexagonal mesostructure of SBA-15 and Ca-SBA-15 supported cobalt catalysts are well retained. However, the mesostructure is destroyed on the Co-Ca/SBA-15 catalyst. Apparently, the doped $\mathrm{Ca}$ on SBA-15 can retain the mesostructure with the direct hydrothermal and the post-synthesis of $\mathrm{Co}-\mathrm{Ca} / \mathrm{SBA}-15$ catalyst cannot retain the mesostructure. High-angle XRD patterns [Fig. 1(B)] indicate that the main diffraction peaks occur at $2 \theta$ values of $31.3^{\circ}, 36.8^{\circ}, 59.4^{\circ}$ and $65.2^{\circ}$, and $36.8^{\circ}$ peak concerning with the crystallographic (311) plane of the cubic $\mathrm{Co}_{3} \mathrm{O}_{4}$ phase (JCPDS No: 76-1802).

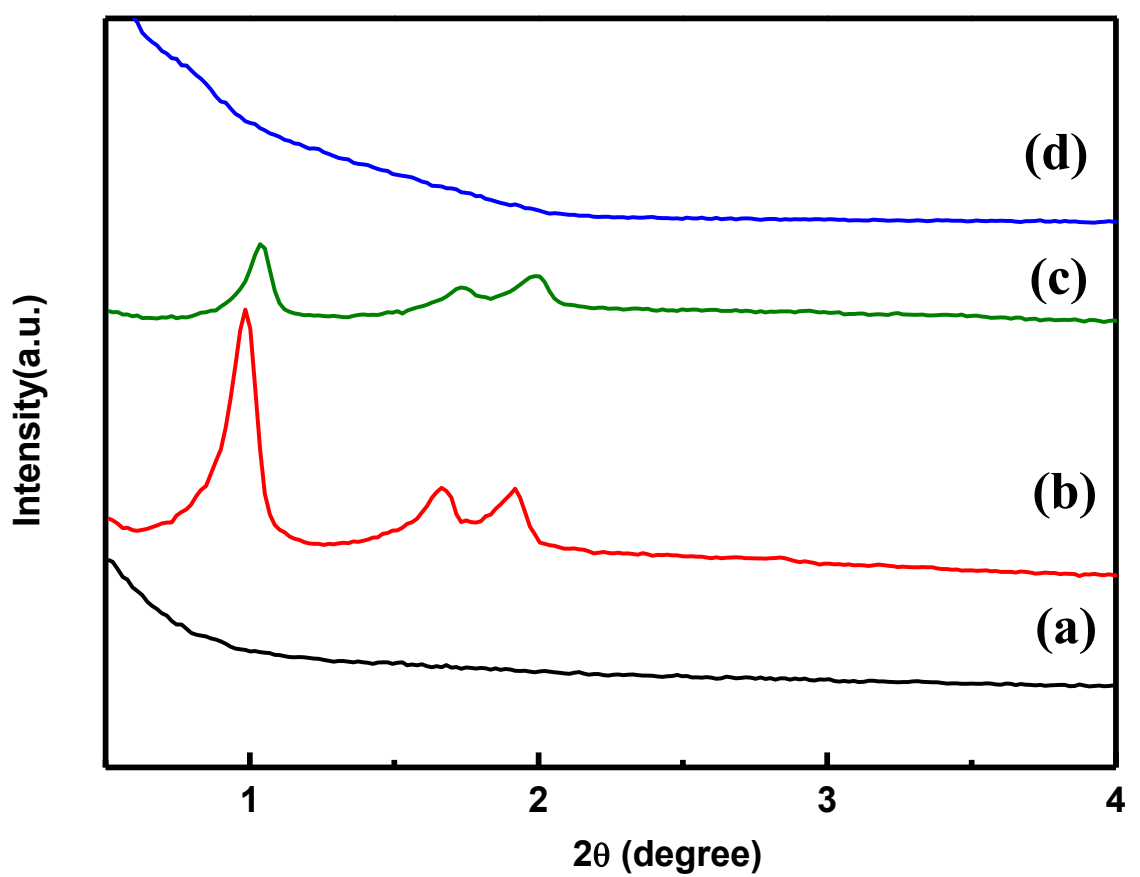

Fig. 1(A) 


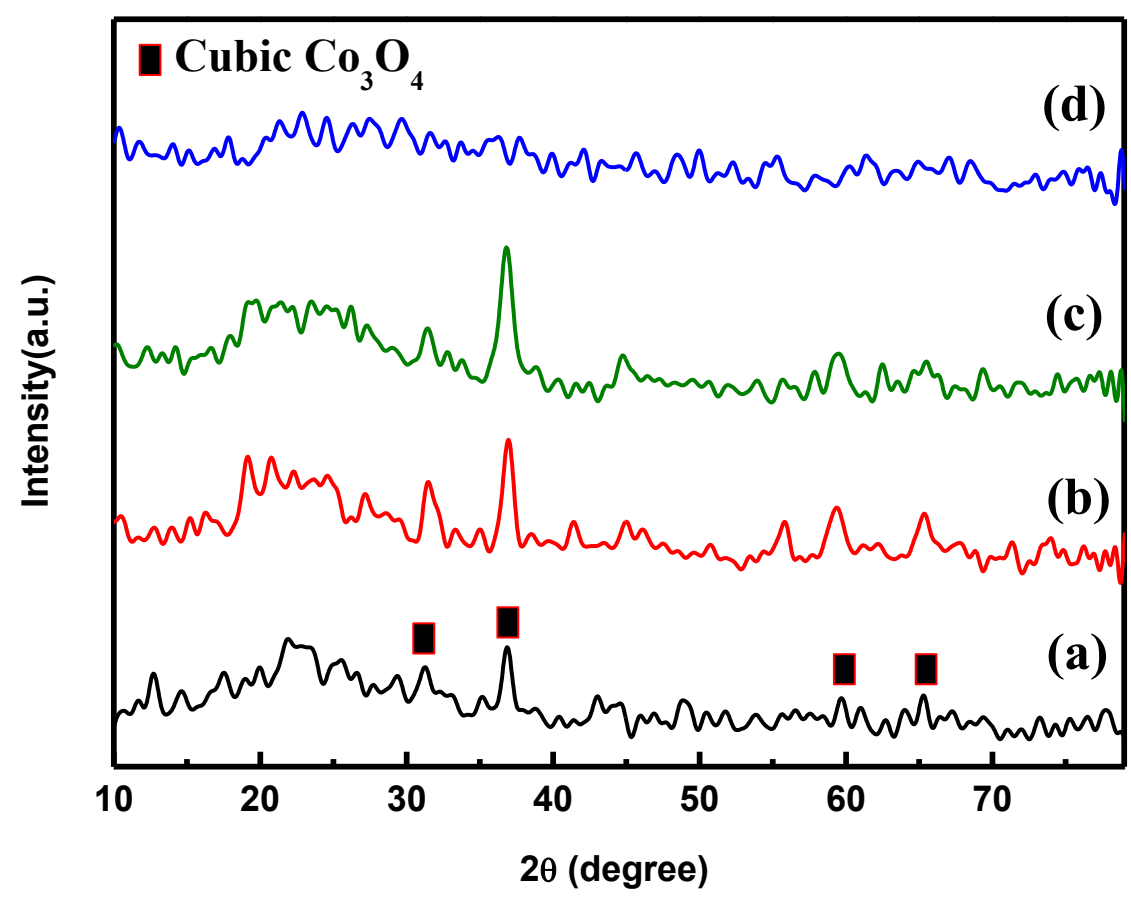

Fig. 1(B)

Fig. 1. XRD patterns of (A) Small angle (B) Wide angle of the silica-supported cobalt catalysts: (a) $\mathrm{Co} / \mathrm{SiO}_{2}$ (b) $\mathrm{Co} / \mathrm{SBA}-15$ (c) $\mathrm{Co} / \mathrm{Ca}-\mathrm{SBA}-15$ (d) $\mathrm{Co}-\mathrm{Ca} / \mathrm{SBA}-15$.

No apparent diffraction peaks observed for the Co-Ca/SBA-15 sample since the mesostructure is destroyed on the $\mathrm{Ca} / \mathrm{SBA}-15$ support which maybe caused the formation of an amorphous $\mathrm{CoSiO}_{3}$ spinel from the $\mathrm{CoO}$ and $\mathrm{SiO}_{2}$. According to the (311) diffraction pattern of $\mathrm{Co}_{3} \mathrm{O}_{4}$ crystalline, the particle size can be calculated using the Scherrer equation [26].

Table 1. Physical property of the supports and silica-supported cobalt catalysts.

\begin{tabular}{lccc}
\hline Sample & $\begin{array}{c}\mathrm{Co}_{3} \mathrm{O}_{4}(311)^{*} \\
\text { Particle size }(\mathrm{nm})\end{array}$ & $\begin{array}{c}\text { Surface area } \\
\left(\mathrm{m}^{2} \cdot \mathrm{g}^{-1}\right)\end{array}$ & $\begin{array}{c}\text { Average } \\
\text { Pore Size }(\mathrm{nm})\end{array}$ \\
\hline $\mathrm{SiO}_{2}$ & - & 506 & 2.1 \\
\hline $\mathrm{Co} / \mathrm{SiO}_{2}$ & 13.8 & 335 & 2.1 \\
\hline $\mathrm{SBA}-15$ & - & 742 & 5.5 \\
\hline $\mathrm{Co} / \mathrm{SBA}-15$ & 11.4 & 348 & 3.8 \\
\hline $\mathrm{Ca}-\mathrm{SBA}-15$ & - & 688 & 4.9 \\
\hline $\mathrm{Co} / \mathrm{Ca}-\mathrm{SBA}-15$ & 8.5 & 420 & 4.0 \\
\hline $\mathrm{Ca} / \mathrm{SBA}-15$ & - & 138 & 5.3 \\
\hline $\mathrm{Co}-\mathrm{Ca} / \mathrm{SBA}-15$ & - & 92 & 3.5 \\
\hline & & 9 &
\end{tabular}


The calculated average crystallite sizes are summarized in the $2^{\text {nd }}$ column of Table 1 . It can be found that the diffraction peaks of $\mathrm{Co}_{3} \mathrm{O}_{4}$ become wider for $\mathrm{Co} / \mathrm{SBA}-15$ and $\mathrm{Co} / \mathrm{Ca}-$ SBA-15 samples. This indicates that the SAB-15 and Ca-SBA-15 supported cobalt catalysts can be well dispersed the active cobalt species and possess high surface area (list in the $3^{\text {rd }}$ column of Table 1). As the mesoporous SBA-15 blocked and/or destroyed, i.e. Ca/SBA-15 support and Co-Ca/SBA-15 catalyst, the surface area decreased rapidly. Moreover, in Fig. 2, TEM images of catalysts are shown to reinforce these differences in terms of morphology and homogeneity of the active phase. The supported particles (dark zones) can be observed over the mesoporous structure of SBA-15 and Ca-SBA-15 supports (long parallel channels in hexagonal array). The intact mesoporous structure is in accordance with the characterization of small-angle XRD detection.
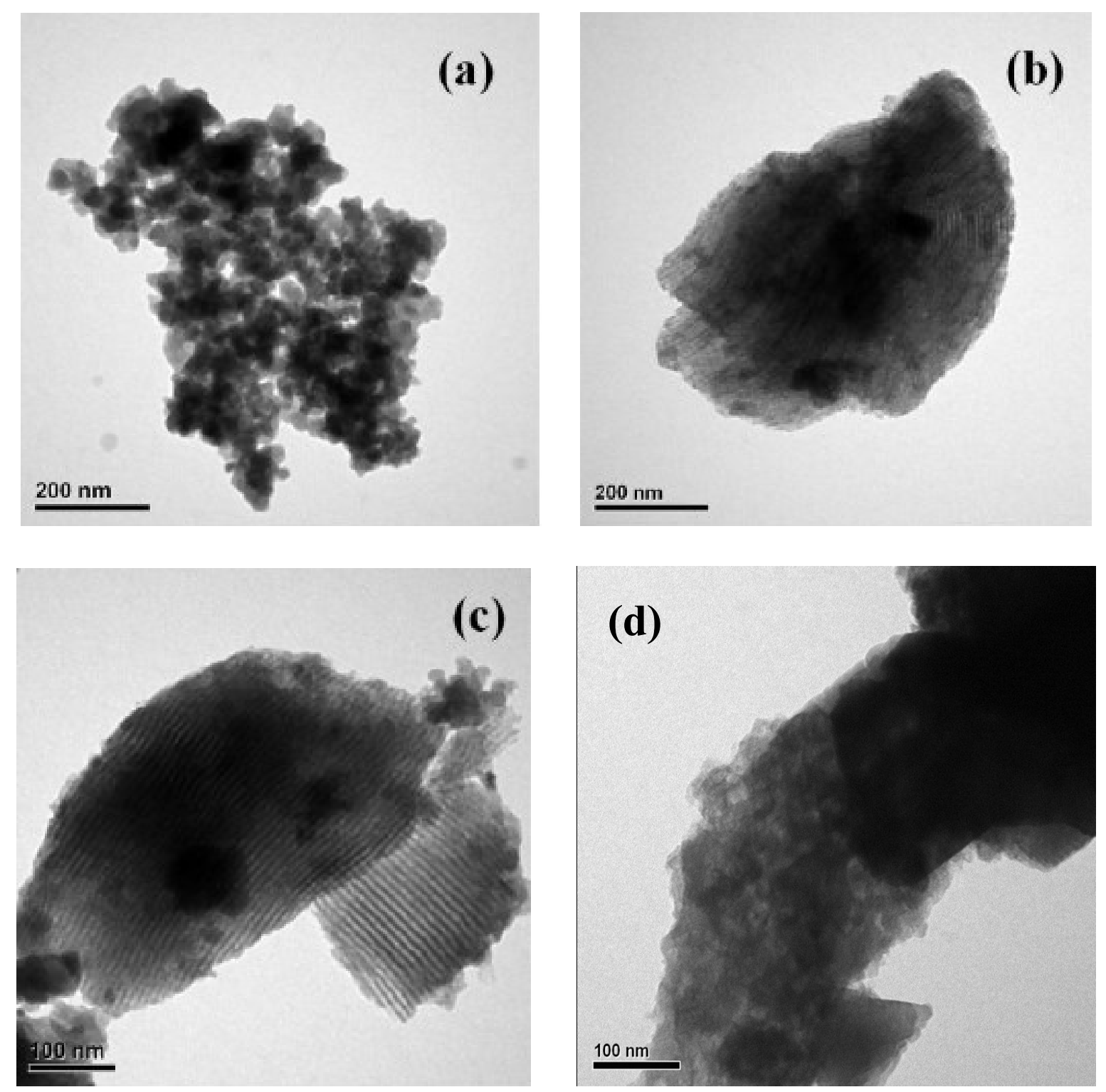

Fig. 2. TEM images of the silica-supported cobalt catalysts: (a) $\mathrm{Co} / \mathrm{SiO}_{2}$ (b) $\mathrm{Co} / \mathrm{SBA}-15$ (c) $\mathrm{Co} / \mathrm{Ca}-$ SBA-15 (d) Co-Ca/SBA-15. 
In order to further identify the cobalt species in these catalysts, the TPR is characterized. Fig. 3 shows the TPR profiles of the silica-supported cobalt catalysts. According to previous report [8], the $\mathrm{Co}_{3} \mathrm{O}_{4}$ could be subsequently reduced to $\mathrm{CoO}$ and $\mathrm{Co}$. Three samples [Fig. 3(a) - (c)] reveal two reduction peaks around 250 to $400{ }^{\circ} \mathrm{C}$ can be assigned as the consecutive reduction of $\mathrm{Co}_{3} \mathrm{O}_{4}$ to $\mathrm{CoO}$ and $\mathrm{CoO}$ to $\mathrm{Co}$, respectively. The slight shift of reductive peaks to low temperature for the Co/Ca-SBA-15 sample [Fig. 3(c)] indicates that a well-dispersed of cobalt oxide may be possible. This is in accordance with the calculated average crystallite size from the XRD detection. Especially, the TPR profile of Co-Ca/SBA-15 catalyst presences low temperature [Fig. 3(d)] and high temperature peaks. According to the literatures reported $[27,28]$, the $\mathrm{CoSiO}_{3}$ spinel was reduced at higher temperature than both $\mathrm{CoO}$ and $\mathrm{Co}_{3} \mathrm{O}_{4}$. It demonstrates that the $\mathrm{Co}-\mathrm{Ca} / \mathrm{SBA}-15$ catalyst contains minor cobaltic oxide (low temperature reduction) and major $\mathrm{CoSiO}_{3}$ spinel (high temperature reduction).

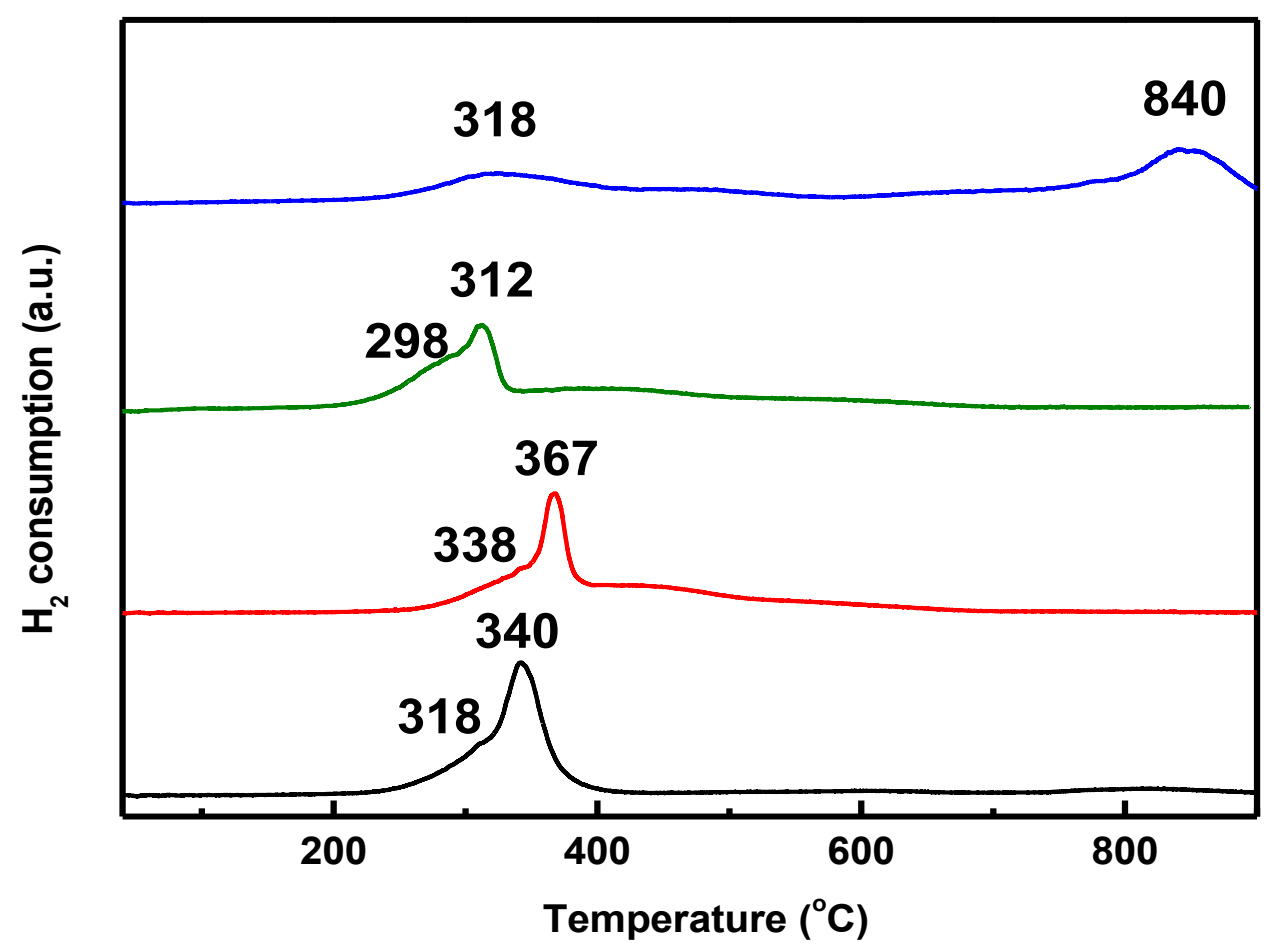

Fig. 3. TPR profiles of the silica-supported cobalt catalysts: (a) $\mathrm{Co} / \mathrm{SiO}_{2}$ (b) $\mathrm{Co} / \mathrm{SBA}-15$ (c) $\mathrm{Co} / \mathrm{Ca}-$ SBA-15 (d) Co-Ca/SBA-15.

\section{2. Catalytic performance}

Fig. 4 summarizes the effect of temperature on $\mathrm{X}_{\mathrm{EtOH}}$ of the silica-supported cobalt catalysts. Also, the catalytic performance of ethanol conversion, products distribution and hydrogen yield are summarized in Table 2. The results confirm that the activity of $\mathrm{Co} / \mathrm{SiO}_{2}$, $\mathrm{Co} / \mathrm{SBa}-15$ and $\mathrm{Co} / \mathrm{Ca}-\mathrm{SiO}_{2}$ catalysts are better than Co-Ca/SBA-15. According to the characterization, the destroyed of mesoporous structure of silica and formation of $\mathrm{CoSiO}_{3}$ spinel for the Co-Ca/SBA-15 sample influences the catalytic activity. The ethanol conversion approaches completion around $400{ }^{\circ} \mathrm{C}\left(\mathrm{T}_{100}\right)$ for the other three samples while only $30 \%$ converts for the $\mathrm{Co}-\mathrm{Ca} / \mathrm{SBA}-15$ sample. Although the activity at low temperature is preferential for the $\mathrm{Co} / \mathrm{SiO}_{2}$, the $\mathrm{T}_{100}\left(400{ }^{\circ} \mathrm{C}\right)$ is higher than both the $\mathrm{Co} / \mathrm{SBA}-15$ and $\mathrm{Co} / \mathrm{Ca}-$ 
SBA-15 samples $\left(\mathrm{T}_{100}=375{ }^{\circ} \mathrm{C}\right)$. When comparing the effect of temperature on the decomposition of acetaldehyde $\left(\mathrm{D}_{\mathrm{T}}\right)$, we see the easy cracking of acetaldehyde promotes the increase of hydrogen yield $\left(\mathrm{Y}_{\mathrm{H} 2}\right)$. The $\mathrm{D}_{\mathrm{T}}$ of the Co/Ca-SBA-15 sample approaches $350{ }^{\circ} \mathrm{C}$ while it is above $375{ }^{\circ} \mathrm{C}$ for the $\mathrm{Co} / \mathrm{SiO}_{2}$ sample and exceeds $500{ }^{\circ} \mathrm{C}$ for the $\mathrm{Co}-\mathrm{Ca} / \mathrm{SBA}-15$ sample. The $\mathrm{Y}_{\mathrm{H} 2}$ exceeds 4.0 around $400{ }^{\circ} \mathrm{C}$ and arrives 4.76 under $500{ }^{\circ} \mathrm{C}$ for the $\mathrm{Co} / \mathrm{Ca}-$ SBA-15 sample. The $\mathrm{Y}_{\mathrm{H} 2}$ approaches 3.45 around $400{ }^{\circ} \mathrm{C}$ and arrives 4.20 under $500{ }^{\circ} \mathrm{C}$ for the $\mathrm{Co} / \mathrm{SiO}_{2}$ sample, while, only 2.0 for the $\mathrm{Co}-\mathrm{Ca} / \mathrm{SBA}-15$ sample at $500{ }^{\circ} \mathrm{C}$. The superior performance of the catalyst supported on the modified mesoporous structure (Ca-SBA-15) of silica is thought to be due to a combination of factors, including the easy reduction, improved metal dispersion and surface area of catalyst.

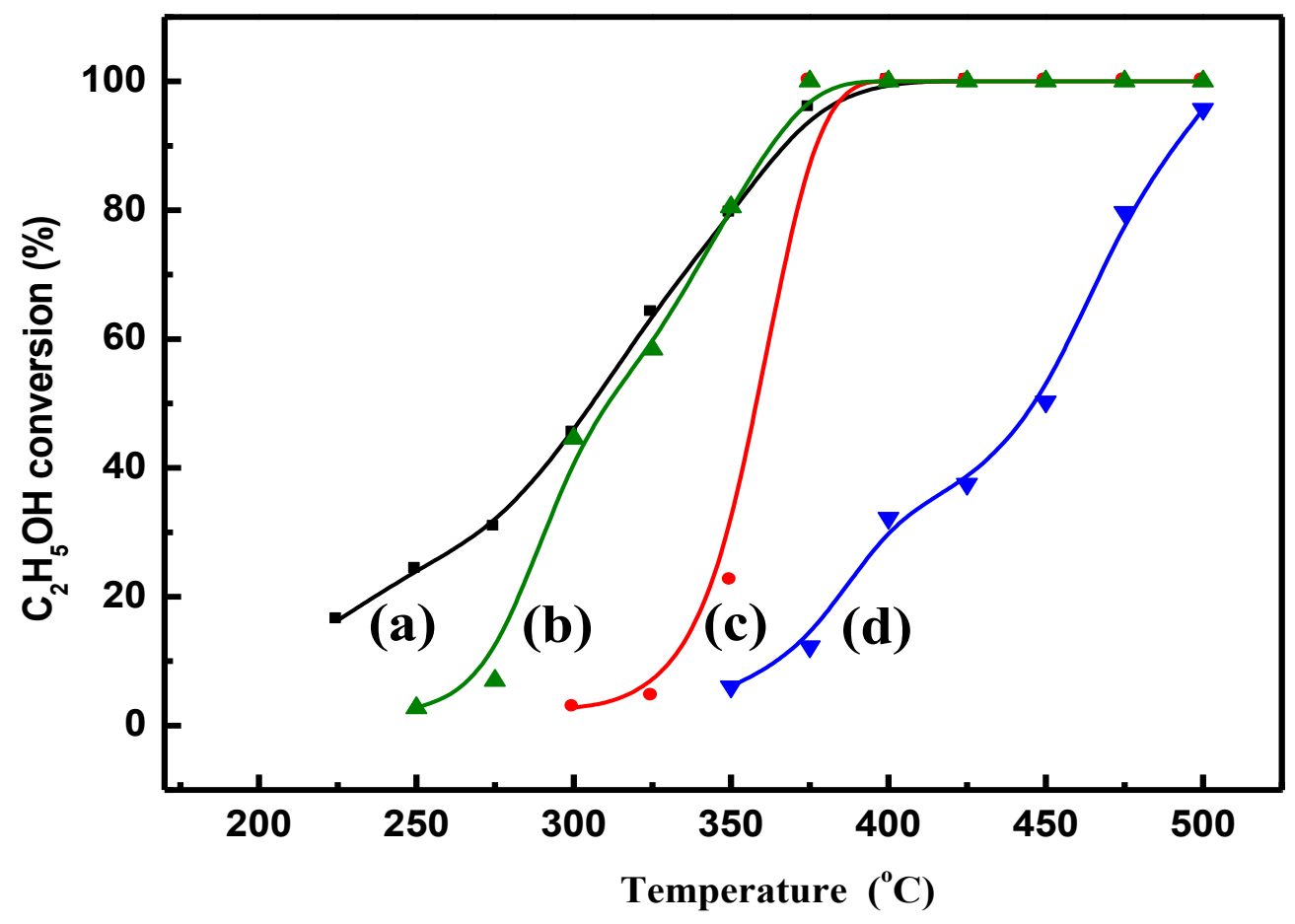

Fig. 4. Comparison of ethanol conversion over the silica-supported cobalt catalysts for the SRE reaction: (a) $\mathrm{Co} / \mathrm{SiO}_{2}$ (b) $\mathrm{Co} / \mathrm{Ca}-\mathrm{SBA}-15$ (c) $\mathrm{Co} / \mathrm{SBA}-15$ (d) $\mathrm{Co}-\mathrm{Ca} / \mathrm{SBA}-15$.

Table 2. Steam reforming of ethanol over silica-supported cobalt catalysts.

\begin{tabular}{|c|c|c|c|c|c|c|c|c|c|c|}
\hline \multirow{2}{*}{ Catalyst } & \multirow{2}{*}{$\begin{array}{c}\mathrm{T}_{\mathrm{R}} \\
\left({ }^{\circ} \mathrm{C}\right)\end{array}$} & \multirow{2}{*}{$\begin{array}{c}\mathrm{X}_{\mathrm{EtOH}} \\
(\%)\end{array}$} & \multirow{2}{*}{$\mathrm{Y}_{\mathrm{H} 2}$} & \multicolumn{7}{|c|}{ Products distribution (mol \%) } \\
\hline & & & & $\mathrm{H}_{2}$ & $\mathrm{CH}_{4}$ & $\mathrm{CO}$ & $\mathrm{CO}_{2}$ & $\mathrm{C}_{2} \mathrm{H}_{4}$ & $\mathrm{C}_{2} \mathrm{H}_{4} \mathrm{O}$ & $\mathrm{C}_{3} \mathrm{H}_{6} \mathrm{O}$ \\
\hline \multirow{7}{*}{$\begin{array}{l}0_{0}^{N} \\
0 \\
0\end{array}$} & 250 & 24.2 & 0.60 & 11.3 & - & - & - & - & 12.9 & - \\
\hline & 300 & 45.4 & 1.50 & 22.2 & 0.55 & 0.79 & 0.17 & - & 21.7 & - \\
\hline & 350 & 79.5 & 2.29 & 44.1 & 1.51 & 4.74 & 1.13 & 0.58 & 25.9 & 1.56 \\
\hline & 375 & 95.9 & 2.79 & 58.2 & 2.93 & 11.2 & 2.96 & 1.29 & 17.6 & 1.64 \\
\hline & 400 & 100 & 3.45 & 66.9 & 6.61 & 7.18 & 19.2 & - & - & 0.10 \\
\hline & 450 & 100 & 4.04 & 70.7 & 5.52 & 2.83 & 20.9 & - & - & - \\
\hline & 500 & 100 & 4.20 & 71.2 & 3.90 & 3.50 & 21.4 & - & - & - \\
\hline
\end{tabular}




\begin{tabular}{|c|c|c|c|c|c|c|c|c|c|c|}
\hline \multirow{6}{*}{\begin{tabular}{l}
$\frac{n}{1}$ \\
\multirow{n}{*}{} \\
0 \\
0 \\
0
\end{tabular}} & 300 & 2.78 & 0.10 & 1.37 & - & - & - & 0.19 & 1.22 & - \\
\hline & 350 & 22.5 & 1.25 & 16.2 & 0.34 & - & 1.51 & 0.15 & 5.47 & - \\
\hline & 375 & 100 & 3.02 & 69.5 & 10.5 & 6.71 & 6.05 & 0.04 & 7.10 & - \\
\hline & 400 & 100 & 3.60 & 70.1 & 11.4 & 2.19 & 16.3 & - & - & - \\
\hline & 450 & 100 & 4.02 & 70.2 & 12.1 & 0.54 & 17.2 & - & - & - \\
\hline & 500 & 100 & 4.18 & 72.5 & 3.80 & 4.20 & 18.5 & - & - & - \\
\hline \multirow{7}{*}{$\begin{array}{l}n \\
\sum_{0}^{n} \\
0 \\
0 \\
0 \\
0 \\
0 \\
0\end{array}$} & 250 & 2.75 & 0.08 & 0.93 & - & - & - & - & 1.82 & - \\
\hline & 300 & 44.6 & 1.85 & 28.9 & 0.42 & 0.36 & - & - & 19.4 & - \\
\hline & 350 & 80.5 & 2.27 & 51.3 & 0.89 & 2.69 & 1.15 & - & 24.5 & - \\
\hline & 375 & 100 & 3.15 & 68.5 & 6.62 & 13.2 & 10.43 & - & 1.39 & - \\
\hline & 400 & 100 & 4.15 & 71.0 & 4.20 & 4.58 & 20.2 & - & - & - \\
\hline & 450 & 100 & 4.32 & 71.5 & 6.42 & 1.46 & 20.6 & - & - & - \\
\hline & 500 & 100 & 4.76 & 72.1 & 3.36 & 1.64 & 22.9 & - & - & - \\
\hline \multirow{5}{*}{ 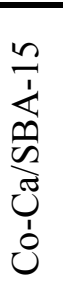 } & 300 & 6.03 & 0.38 & 2.99 & 0.19 & - & - & - & 2.85 & - \\
\hline & 350 & 12.3 & 0.82 & 6.32 & 0.41 & - & 0.17 & - & 5.20 & - \\
\hline & 400 & 32.2 & 1.32 & 15.8 & 0.53 & 0.29 & 0.49 & 0.49 & 14.8 & - \\
\hline & 450 & 50.3 & 1.67 & 24.6 & 0.53 & 0.50 & 0.84 & 0.90 & 23.2 & - \\
\hline & 500 & 95.7 & 2.05 & 50.1 & 1.00 & 1.19 & 1.56 & 1.54 & 38.8 & - \\
\hline
\end{tabular}

*Water not included.

According to the products distribution with temperature, the pathway of the SRE reaction over silica-supported cobalt catalysts is proposed in Scheme 1.

\section{$\mathrm{CH}_{3} \mathrm{CH}_{2} \mathrm{OH}$}

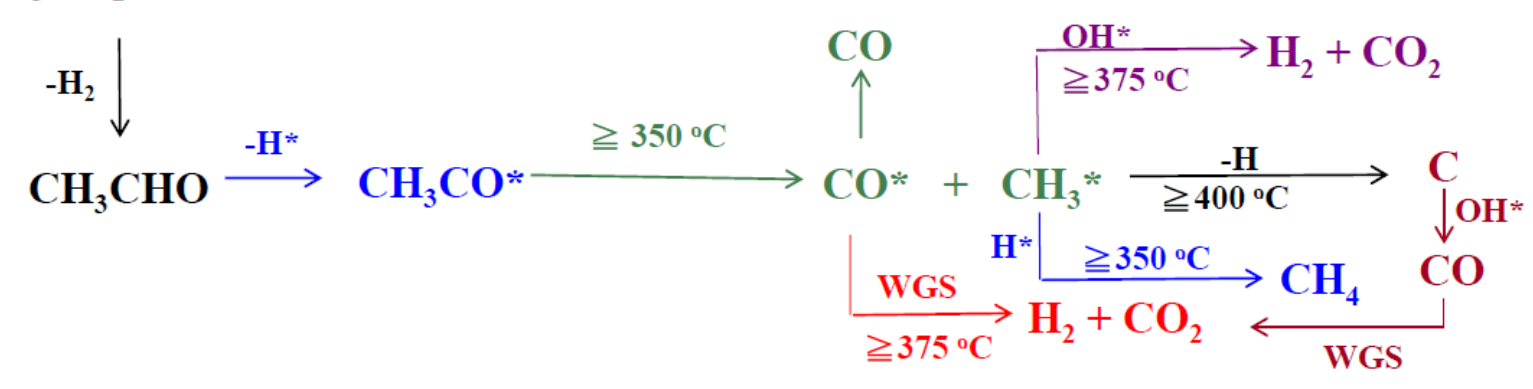

Scheme 1. Reaction pathway for the SRE reaction over silica-supported cobalt catalysts.

The low temperature $\left(<375^{\circ} \mathrm{C}\right)$ presents large amounts of $\mathrm{CH}_{3} \mathrm{CHO}$ and decreasing amounts of $\mathrm{CH}_{3} \mathrm{CHO}$ with increase of temperature that accompanies the increase of $\mathrm{Y}_{\mathrm{H} 2}$. Apparently, the dehydrogenation of ethanol to acetaldehyde is the initial step. As the temperature rises, the major reaction is the decomposition of acetaldehyde into methane and $\mathrm{CO}$. 


$$
\begin{aligned}
& \mathrm{C}_{2} \mathrm{H}_{5} \mathrm{OH} \rightarrow \mathrm{CH}_{3} \mathrm{CHO}+\mathrm{H}_{2} \\
& \mathrm{CH}_{3} \mathrm{CHO} \rightarrow \mathrm{CH}_{4}+\mathrm{CO}
\end{aligned}
$$

In the presence of water, the side-reactions of water gas shift (WGS) reaction, steam reforming of methane, consecutive dehydrogenation from the methyl group and/or further react with the surface anchored $\mathrm{OH}\left(\mathrm{OH}_{-}{ }^{*}\right)$ species may also occur.

$$
\begin{aligned}
& \mathrm{CO}+\mathrm{H}_{2} \mathrm{O} \rightarrow \mathrm{CO}_{2}+\mathrm{H}_{2} \\
& \mathrm{CH}_{4}+\mathrm{H}_{2} \mathrm{O} \rightarrow \mathrm{CO}+3 \mathrm{H}_{2}
\end{aligned}
$$

Due to the endothermic nature of steam reform of methane $\left(\Delta \mathrm{H}_{\mathrm{r}}=206 \mathrm{~kJ} / \mathrm{mol}\right)$, the reaction (7) is carried out at high temperatures (around $600 \sim 900{ }^{\circ} \mathrm{C}$ ) to achieve high conversion rates [29-31]. While, the methyl group can further react with the surface anchored $\mathrm{OH}$ species at lower temperature to form carbon monoxide and hydrogen [32] and/or consecutive dehydrogenation of methyl causes the formation of deposited carbon. Follow, accompanied the coal gasification and WGS reaction with $\mathrm{CO}$ oxidation [33] derives the minor $\mathrm{CO}$ distribution.

$$
\begin{aligned}
& \mathrm{CH}_{3}{ }^{*}+\mathrm{OH}^{*} \rightarrow \mathrm{CO}+2 \mathrm{H}_{2} \\
& \mathrm{CH}_{3^{-}}{ }^{*} \rightarrow \mathrm{CH}_{2^{-}}{ }^{*} \rightarrow \mathrm{CH}_{-} * \rightarrow \mathrm{C} \\
& \mathrm{C}+\mathrm{OH}^{*} * \mathrm{CO}
\end{aligned}
$$

Carbon deposition is considered to be the main cause for the deactivation of Co-based catalyst in the steam reforming of ethanol [34].

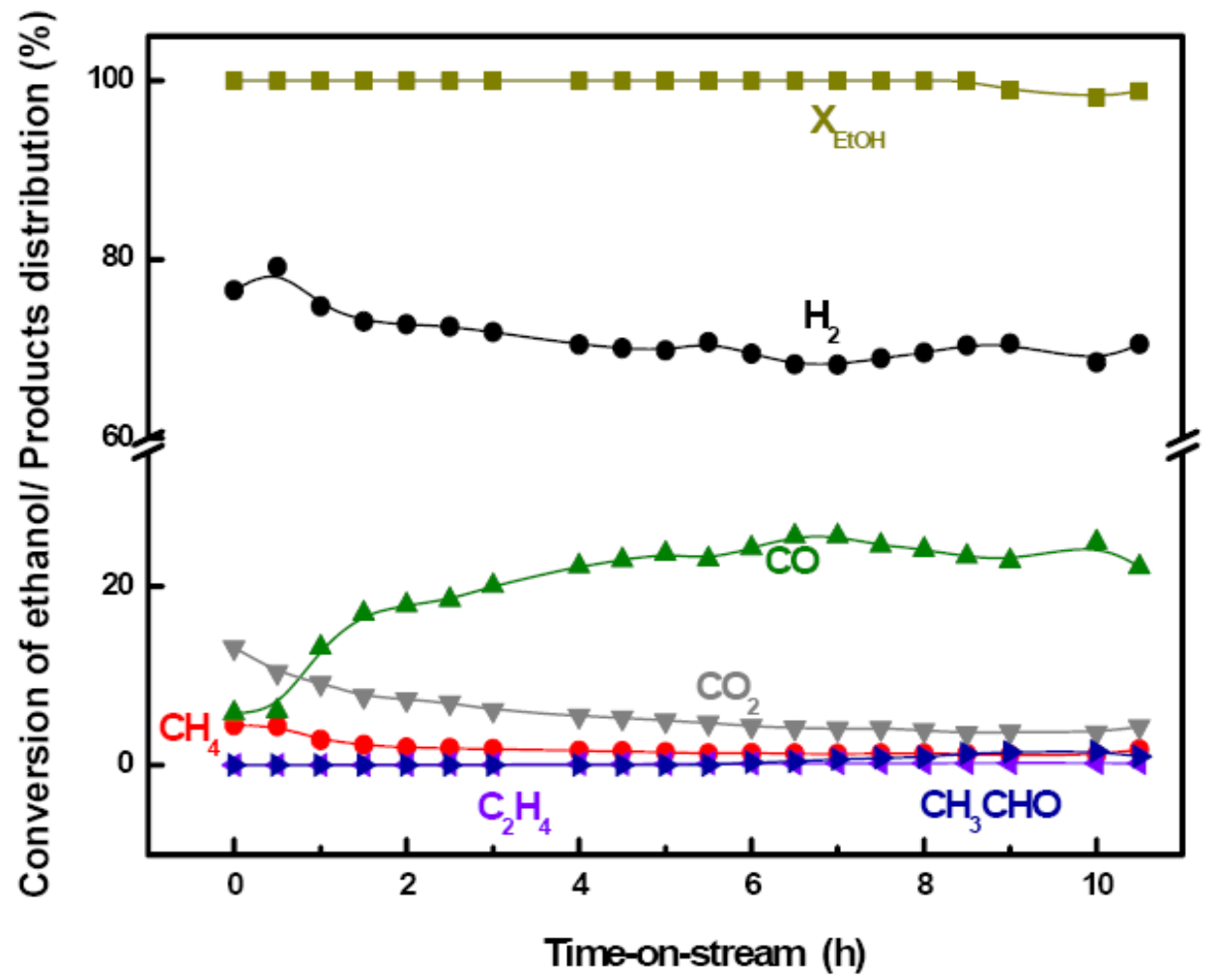

Fig. 5(A) 


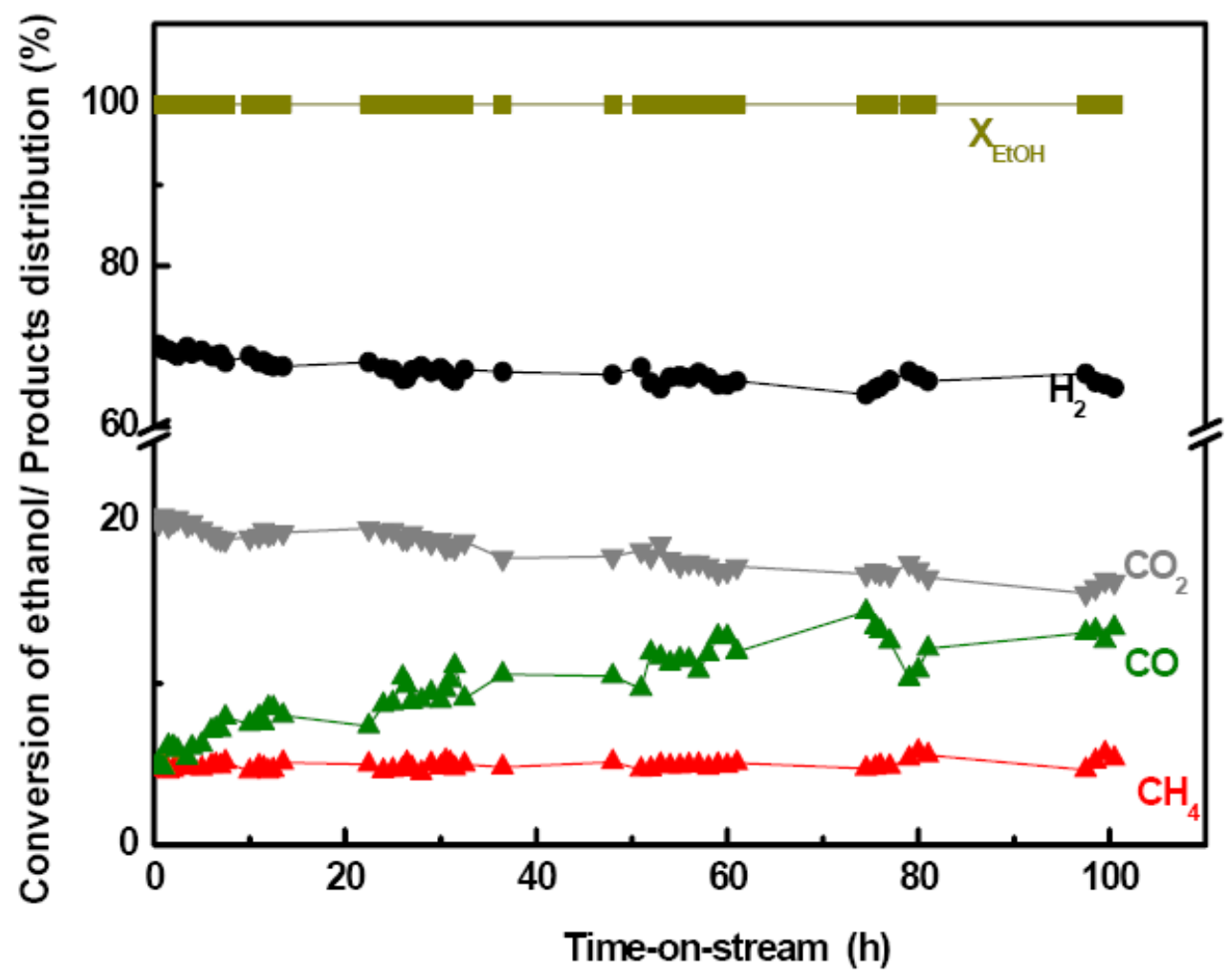

Fig. 5(B)

Fig. 5. Time-on-stream of SRE reaction at $500{ }^{\circ} \mathrm{C}:(\mathrm{A}) \mathrm{Co} / \mathrm{SBA}-15$ (B) $\mathrm{Co} / \mathrm{Ca}-\mathrm{SBA}-15$.

The effect of support can be tuned with alkaline earth to obtain sufficient acid-base sites $[35,36]$ for water splitting into $\mathrm{OH}$ group and limited acidic sites to avoid the formation of coke, which results from the polymerization of olefin.

Fig. 5 compares the conversion and products distribution as a function of time-onstream (TOS) during the SRE reaction over both Co/SBA-15 and Co/Ca-SBA-15 catalysts at $500{ }^{\circ} \mathrm{C}$. The Co/SBA-15 catalyst retained complete conversion for around $8 \mathrm{~h}$ and the $\mathrm{S}_{\mathrm{H} 2}$ approached $70 \%$, while the $\mathrm{S}_{\mathrm{CO}}$ was higher than $20 \%$ after $5 \mathrm{~h}$. From the decrease of $\mathrm{CO}_{2}$ and increase of $\mathrm{CO}$, the reverse water gas shift (RWGS) reaction may be occurred.

$$
\mathrm{CO}_{2}+\mathrm{H}_{2} \rightarrow \mathrm{CO}+\mathrm{H}_{2} \mathrm{O}
$$

Modification of SBA-15 with Ca using direct hydrothermal can relieve the carbon deposition to enhance the durability of catalyst. The $\mathrm{Co} / \mathrm{Ca}-\mathrm{SBA}-15$ catalyst displays the better durability. The catalytic activity maintains over $100 \mathrm{~h}$ and the $\mathrm{S}_{\mathrm{H} 2}$ also approaches $68 \%$, while the $\mathrm{S}_{\mathrm{CO}}$ is higher than $10 \%$ after $50 \mathrm{~h}$.

The catalyst can maintain the long-term stability attributed to the deposited coke can be removed rapidly by the anchored hydroxyl and accompanies the WGS reaction to maintain the catalytic performance. The model of elimination of deposited coke on the $\mathrm{Co} / \mathrm{Ca}-\mathrm{SBA}-15$ catalyst shows in the Scheme 2.

The qualitative analysis of TEM and quantitative analysis of EA can be used to characterize the deposited carbon on the surface of catalyst. Fig 6 shows the TEM images for 
the Co/SBA-15 and Co/Ca-SBA-15 catalysts after the TOS test at $500{ }^{\circ} \mathrm{C}$. Despite the higher stability of $\mathrm{Co} / \mathrm{Ca}-\mathrm{SBA}-15$ catalyst, the deposited carbon cannot be completely suppressed; rather catalyst deactivation can only be slow down.

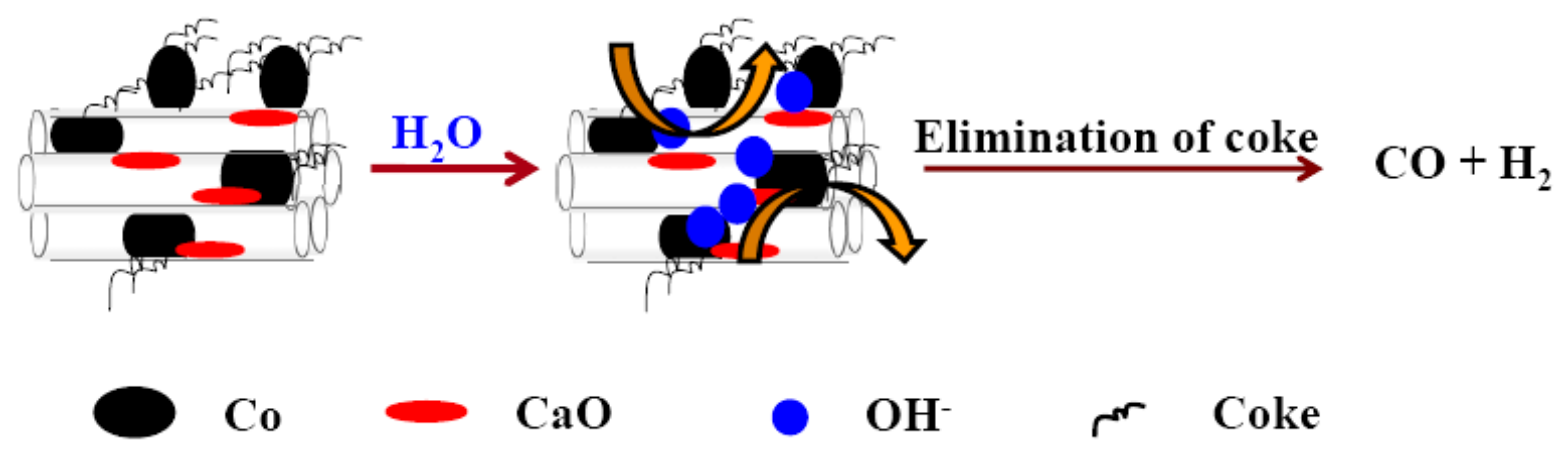

Scheme 2. Model of elimination of deposited carbon on the Co/Ca-SBA-15 catalyst.

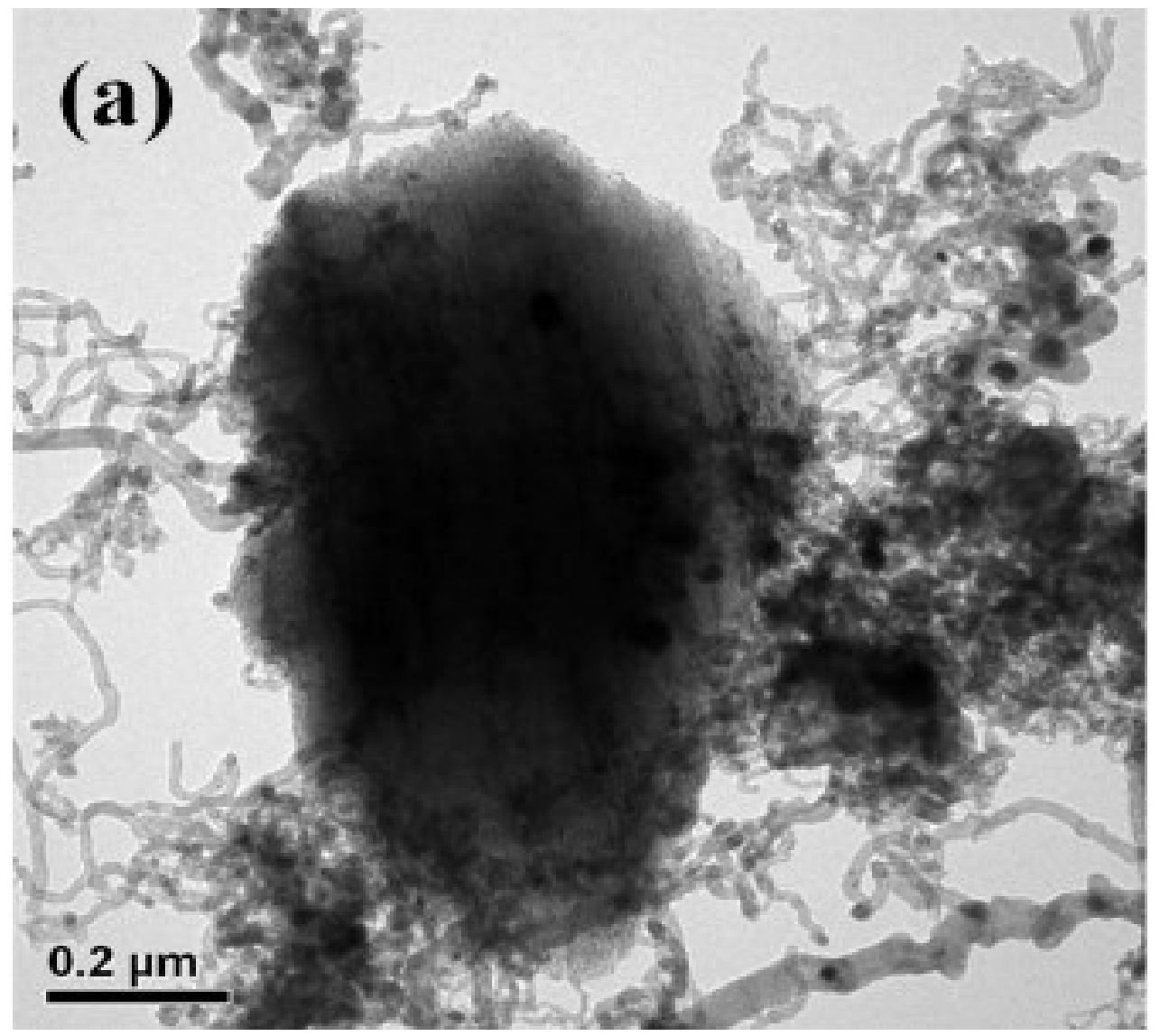

Fig. 6(A) 


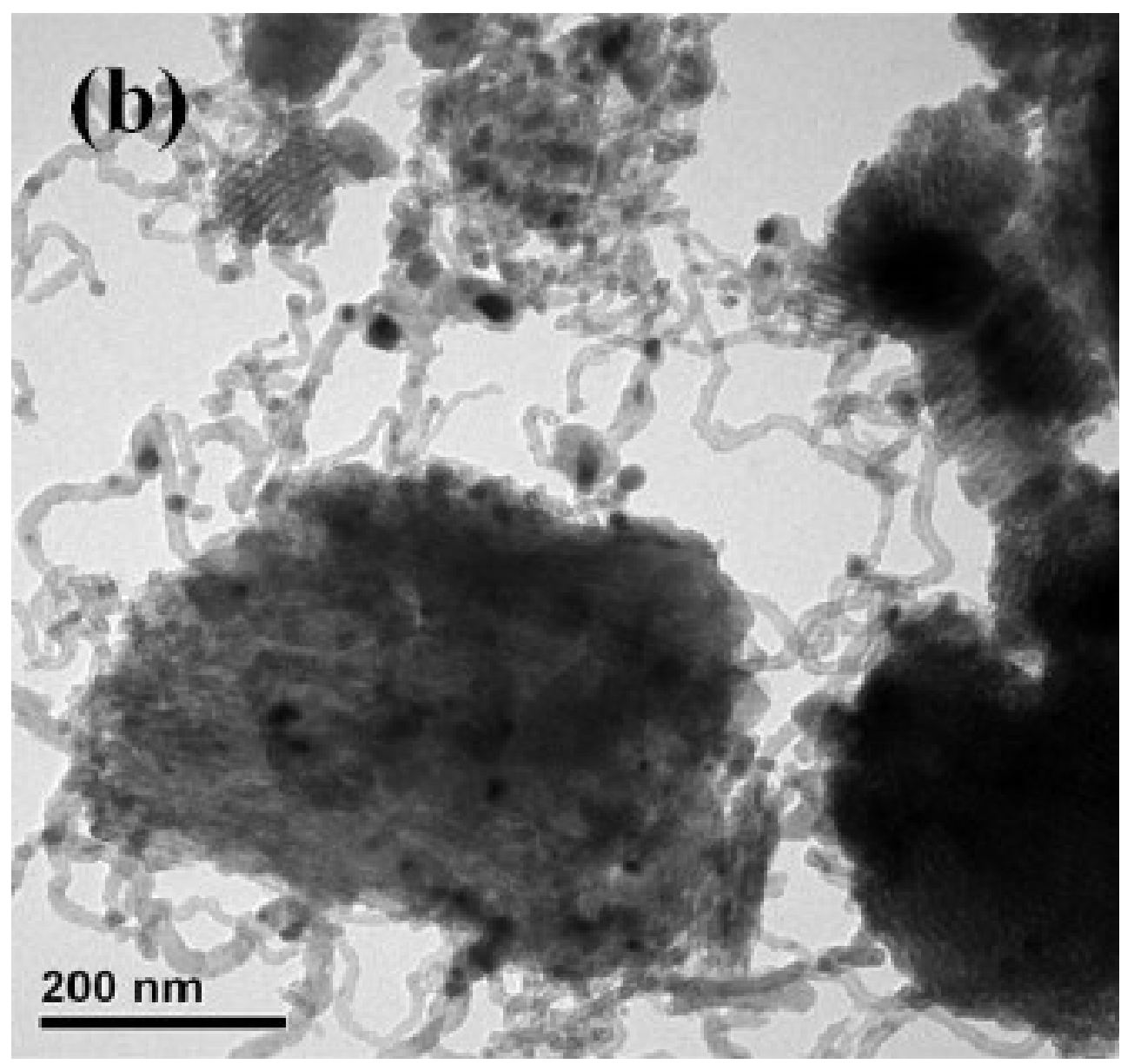

Fig. 6(B)

Fig. 6. TEM images of spent catalysts: (A) Co/SBA-15 (B) Co/Ca-SBA-15.

The higher stability could be due to the lower deposited carbon. Also, the EA analysis (list in the last two columns in Table 3) confirms that the deposited carbon is $5.7 \%(11 \mathrm{~h}$ TOS, rate is $\left.0.52 \% \cdot \mathrm{h}^{-1}\right)$ and $8.2 \%\left(100 \mathrm{~h} \mathrm{TOS}\right.$, rate is $\left.0.08 \% \cdot \mathrm{h}^{-1}\right)$, respectively for the Co/SBA-15 and Co/Ca-SBA-15 catalysts. The TEM images show that the deposited carbon appears as filaments and tubes emerged with the cobalt, or as a rather coating carbon covered on the surface of catalyst. According to the deactivation with deposited carbon, the coating carbon would shorten the lifetime of catalyst rather than the filaments carbon [37], which convinced with our results. Moreover, the spent Co/Ca-SBA-15 catalyst with well thermal stability maintains the mesoporous structure and retards the growth of Co by sintering [Fig 6(B)] after the SRE reaction. The results obtained for the ethanol conversion, $\mathrm{CH}_{4}$ and $\mathrm{CO}$ composition, hydrogen yield and the amount of carbon on the silica-supported cobalt catalysts, which were determined from temperature-programmed experiments of the spent catalyst after the time-on-stream, are summarized in Table 3 . The catalytic performance of these catalysts showed that the support played an important role in the improvement of the stability in the presence of a deactivating impurity. Due to a combination of factors, including the easy reduction, improved metal dispersion and surface area of catalyst, the Co/Ca-SBA15 catalyst displays the better catalytic activity and durability among these series cobaltbased catalysts. 
Table 3. Catalytic performance and carbon deposition on the silica-supported cobalt catalysts.

\begin{tabular}{ccccccccc}
\hline Catalyst & $\begin{array}{c}\mathrm{T}_{\mathrm{R}} \\
\left({ }^{\circ} \mathrm{C}\right)\end{array}$ & $\begin{array}{c}\mathrm{X}_{\mathrm{EtOH}} \\
(\%)\end{array}$ & $\begin{array}{c}\mathrm{S}_{\mathrm{CH} 4} \\
(\%)\end{array}$ & $\begin{array}{c}\mathrm{S}_{\mathrm{CO}} \\
(\%)\end{array}$ & $\mathrm{Y}_{\mathrm{H} 2}$ & $\begin{array}{c}\text { TOS* } \\
(\mathrm{h})\end{array}$ & $\begin{array}{c}\text { EA } \\
(\%) * *\end{array}$ & $\begin{array}{c}\text { Rate } \\
(\% / \mathrm{h})\end{array}$ \\
\hline $\mathrm{Co} / \mathrm{SiO}_{2}$ & 500 & 100 & 3.90 & 3.50 & 4.20 & 10 & 7.8 & 0.78 \\
\hline $\mathrm{Co} / \mathrm{SBA}-15$ & 500 & 100 & 3.80 & 4.20 & 4.18 & 11 & 5.7 & 0.52 \\
\hline $\mathrm{Co} / \mathrm{Ca}-\mathrm{SBA}-15$ & 500 & 100 & 3.36 & 1.64 & 4.76 & 100 & 8.2 & 0.08 \\
\hline $\mathrm{Co}-\mathrm{Ca} / \mathrm{SBA}-15$ & 500 & 95.7 & 1.00 & 1.19 & 2.05 & - & - & - \\
\hline \multicolumn{2}{c}{$*$ Time-on-stream of SRE reaction at $500{ }^{\circ} \mathrm{C}$} & $* *$ Measured by elemental analysis. &
\end{tabular}

\section{CONCLUSION}

The highly efficient conversion of ethanol to hydrogen with very low coke deposition indicates that the SRE on Ca-modified Co/SBA-15 catalysts is a promising design for the development of hydrogen production. The modification of SBA-15 with Ca using direct hydrothermal can relieve the carbon deposition to enhance the durability of catalyst that attributed to the deposited coke can be removed rapidly by the anchored hydroxyl and accompanies the WGS reaction to maintain the catalytic performance. The Co/Ca-SBA-15 catalyst exhibits better catalytic activity and durability among these catalysts. The $\mathrm{Y}_{\mathrm{H} 2}$ approaches 4.76 at $500{ }^{\circ} \mathrm{C}$ and less coke deposition. Furthermore, the durability test of this catalyst approaches $100 \mathrm{~h}$ at $500{ }^{\circ} \mathrm{C}$ and does not deactivate.

\section{Acknowledgement}

We are pleased to acknowledge the financial support for this study by the National Science Council of the Republic of China under contract numbers of NSC 99-2113-M-606-001-MY3 and 102-2113-M-606-001-.

\section{References}

[1] M. C. Batista, R. K. S. Santos, E. M. Assaf, J. M. Assaf, E. A. Ticianelli, Journal of Power Sources 134 (2004) 27-32.

[2] D. K. Liguras, D. I. Kondarides, X. E. Verykios, Applied Catalysis B: Environmental 43 (2003) 345-354.

[3] G. Maggio, S. Freni, S. Cavallaro, Journal of Power Sources 74 (1998) 17-23.

[4] L. F. Brown, International Journal of Hydrogen Energy 26 (2001) 381-397.

[5] J. Llorca, N. Homs, J. Sales, P. Ramirez de la Piscina, Journal of Catalysis 209 (2002) 306-317.

[6] A. Haryanto, S. Femando, N. Murali, S. Adhikari, Energy \& Fuels 19 (2005) 2098-2106.

[7] P. K. Cheekatamarla, C. M. Finnerty, Journal of Power Sources 160 (2006) 490-499. 
[8] C. B. Wang, C. C. Lee, J. L. Bi, J. Y. Siang, J. Y. Liu, C. T. Yeh, Catalysis Today 146 (2009) 76-81.

[9] J. Y. Siang, C. C. Lee, C. H. Wang, W. T. Wang, C. Y. Deng, C. T. Yeh, C. B. Wang, International Journal of Hydrogen Energy 35 (2010) 3456-3462.

[10] S. W. Liu, J.Y. Liu, Y.H. Liu, Y.H. Huang, C.T. Yeh, C.B. Wang, Catalysis Today 164 (2011) 246-250.

[11] F. Haga, T. Nakajima, H. Miya, S. Mishima, Catalysis Letters 48 (1997) 223-227.

[12] J. Llorca, P. Ramirez de la Piscina, J. A. Dalmon, J. Sales, N. Homs, Applied Catalysis B: Environmental 43 (2003) 355-369.

[13] J. M. Pigos, C. J. Brooks, G. Jacobs, B. H. Davis, Applied Catalysis A: General 328 (2007) 14-26.

[14] C. H. Wang, K. F. Ho, J. Y. Z. Chiou, C. L. Lee, S.Y . Yang, C. T. Yeh, C. B. Wang, Catalysis Communications 12 (2011) 854-858.

[15] Z. Cheng, Q. Wu, J. Li, Q. Zhu, Catalysis Today 30 (1996) 147-155.

[16] D. H. Olson, G. T. Kokotailo, S. L. Lawton, W. M. Meler, The Journal of Physical Chemistry 85 (1981) 2238-2243.

[17] C. T. Kresge, M. E. Leonowicz, W. J. Roth, J. C. Vartuli, J. S. Beck, Nature 359 (1992) 710-712.

[18] D. Zhao, J. Feng, Q. Huo, N. Melosh, G. H. Fredrickson, B. F. Chmelka, G. D. Stucky, Science 279 (1998) 548-552.

[19] A. J. Vizcaíno, A. Carrero, J. A. Calles, International Journal of Hydrogen Energy 32 (2007) 1450-1461.

[20] A. Carrero, J. A. Calles, A. J. Vizcaíno, Applied Catalysis A: General 327 (2007) 82-94.

[21] A. J. Vizcaíno, A. Carrero, J. A. Calles, Catalysis Today 146 (2009) 63-70.

[22] J. A. Calles, A. Carrero, A. J. Vizcaíno, Microporous and Mesoporous Materials 119 (2009) 200-207.

[23] A. Carrero, J. A. Calles, A. J. Vizcaino, Chemical Engineering Journal 163 (2010) 395-402.

[24] K. Wang, X. Li, S. Ji, X. Shi, J. Tang, Energy \& Fuels 23 (2009) 25-31.

[25] H. Wang, Y. Liu, L. Wang, Y. Qin, Chemical Engineering Journal 145 (2008) 25-31.

[26] H. P. Klug, L. E. Alexander, X-ray Diffraction Procedures for Polycrystalline and Amorphous Materials, Wiley, New York, 1962.

[27] S. R. Bohlen, A. L. Boettcher, Geophysical Research Letters 8 (1981) 575-578.

[28] C. B. Wang, C. W. Tang, H. C. Tsai, S. H. Chien, Catalysis Letters 107 (2006) 223-230.

[29] M. Mamak, N. Coombs, G. Ozin, Advanced Materials, 12 (2000) 198-202.

[30] P. Bera, S. Mitra, S. Sampath, M. S. Hegde, Chemical Communications 10 (2001) 9 27-928.

[31] T. Takeguchi, S.N. Furukawa, M. Inoue, Journal of Catalysis 202 (2001) 14-24. 
[32] M. Domok, M. Toth, J. Rasko, A. Erdohelyi, Applied Catalysis B: Environmental 69 (2007) 262-272.

[33] C. W. Tang, C. C. Kuo, M. C. Kuo, C. B. Wang, S. H. Chien, Applied Catalysis A: General 309 (2006) 37-43.

[34] H. Song, U. S. Ozkan, Journal of Catalysis 261 (2009) 66-74.

[35] R. M. Navarro, M. A. Pena, J. L. G. Fierro, Chemical Reviews 107 (2007) 3952-3991.

[36] L. S. Carvalho, A. R. Martins, P. Reyes, M. Oportus, A. Albonoz, V. Vicentini, M. C. Rangel, Catalysis Today 142 (2009) 52-60.

[37] I. Suelves, M. J. Lázaro, R. Moliner, B. M. Corbella, J. M. Palacios, International Journal of Hydrogen Energy 30 (2005) 1555-1567. 